\title{
Epidemiology of infections with cytomegalovirus (CMV) and herpes simplex virus in promiscuous women: absence of exogenous reinfection with CMV
}

\author{
P WERTHEIM, J GALAMA, J GEELEN, C BUURMAN, AND J VAN DER NOORDAA \\ From the Virology Section, Department of Medical Microbiology, University of Amsterdam, Academic \\ Medical Centre, Amsterdam, the Netherlands
}

SUMMARY Herpes simplex virus (HSV) was shed from the genital tracts of $26(15 \%)$ and cytomegalovirus (CMV) from $19(11 \%)$ of 177 promiscuous women. Virus excretion was especially common (HSV $41 \%$ and CMV 19\%) in the youngest age group (aged 19 or less).

Episodic shedding of CMV was studied by restriction enzyme analysis of the viral DNAs prepared from repeat isolates. Repeat isolates from each woman were identical, which indicated that recurrent shedding of CMV resulted from endogenous reinfection. Even under conditions of high exposure no exogenous reinfection with CMV could be shown, which indicated that exogenous reinfection is rare.

\section{Introduction}

Sexual transmission of herpes simplex virus type II (HSV II) and cytomegalovirus (CMV) after primary infection and subsequent recurrences due to endogenous reinfection have been well documented. Exogenous reinfection with $\mathrm{HSV} \mathrm{II}^{1}$ and $\mathrm{CMV}^{2}$ has occasionally been reported, but no data concerning the incidence of exogenous reinfection were presented in these reports.

Recently Schmidt et al showed that exogenous reinfection with HSV is apparently rare, as it was not detected in a group of 24 women with recurring symptomatic episodes of genital herpes. ${ }^{3}$

Our present study of the epidemiology of infections with HSV and CMV in promiscuous women failed to detect exogenous reinfection with CMV, which indicates that exogenous reinfection with $\mathrm{CMV}$ must also be rare.

\section{Patients and methods}

STUDY POPULATION

We studied 177 promiscuous women (prostitutes

Address for reprints: Professor J van der Noordaa, Virology Section, Department of Medical Microbiology, University of Amsterdam, Academic Medical Centre, Meibergdreef 15, 1105 AZ Amsterdam, the Netherlands

Accepted for publication 11 March 1985 addicted to heroin) aged 15 to 58 (mean 23) who voluntarily attended a clinic for sexually transmitted diseases (STD) of the Municipal Health Service in Amsterdam for a total of 497 visits. The high incidence of STD in this group is illustrated by the fact that in 1982 there were 10 new cases of syphilis, 140 of gonorrhea, and 124 of trichomoniasis. ${ }^{4}$

\section{VIRUS CULTURE AND TYPING}

Sterile cotton tipped swabs were used to obtain cervical specimens. These were immersed in Hank's solution with penicillin, streptomycin, and nystatin and were inoculated in duplicate within one hour on diploid human fetal lung cells. Cultures were examined twice weekly for six weeks. HSV typing was based on giant cell formation, and adenovirus typing was performed by neutralisation and by restriction enzyme analysis; the reference strain adenovirus type 37 was provided by Dr J C de Jong (Public Health Laboratory, Bilthoven). Differentiation between types of CMV was performed as described previously, ${ }^{5}$ using the restriction enzymes Eco RI and Hind III and the reference strains AD 169 and SG.

\section{Results}

Table I shows the number of women in the different age groups and the number of specimens available for investigation from each age group. We obtained 497 specimens from 177 women (a mean sampling rate of $2 \cdot 8$ ), which yielded $32 \mathrm{HSV}$ isolates, $26 \mathrm{CMV}$ isolates, 
TABLE I Number of samples available/number of women in each age group (mean samples in parentheses)

\begin{tabular}{|c|c|c|c|c|}
\hline \multirow[b]{2}{*}{ Age (yrs) } & \multicolumn{3}{|c|}{ Women yielding: } & \multirow[b]{2}{*}{ Total } \\
\hline & I Sample & 2/3 Samples & $\geqslant 4$ Samples & \\
\hline $\begin{array}{c}\leqslant 19 \\
20-25 \\
26-30 \\
>30\end{array}$ & $\begin{array}{l}12 / 12(1) \\
47 / 47(1) \\
19 / 19(1) \\
13 / 13(1)\end{array}$ & $\begin{array}{l}21 / 9(2 \cdot 3) \\
76 / 29(2 \cdot 6) \\
30 / 12(2 \cdot 5) \\
13 / 5(2 \cdot 6)\end{array}$ & $\begin{array}{r}31 / 6(5 \cdot 2) \\
142 / 17(8 \cdot 4) \\
44 / 6(7 \cdot 3) \\
49 / 2(24 \cdot 5)\end{array}$ & $\begin{aligned} 64 / 27(2 \cdot 4) \\
265 / 93(2 \cdot 8) \\
93 / 37(2 \cdot 5) \\
75 / 20(3 \cdot 8)\end{aligned}$ \\
\hline Total & 91/91 (1) & $140 / 55(2 \cdot 5)$ & $266 / 31 \quad(8 \cdot 6)$ & $497 / 177(2 \cdot 8)$ \\
\hline
\end{tabular}

TABLE II Number of women shedding herpes simplex virus (HSV) and cytomegalovirus (CMV)/number in each age group (women shedding viruses as \% of those in each age group in parentheses)

\begin{tabular}{|c|c|c|c|c|}
\hline \multirow[b]{2}{*}{ Age (yrs) } & \multicolumn{3}{|c|}{ Women yielding: } & \multirow[b]{2}{*}{ Total } \\
\hline & I Sample & 2/3 Samples & $\geqslant 4$ Samples & \\
\hline $\begin{array}{c}\text { Shedding } \\
\leq 19 \\
20-25 \\
26-30 \\
>30\end{array}$ & $\begin{array}{ll}3 / 12 & (25) \\
3 / 47 & (6) \\
0 / 19 & \\
1 / 13 & (8)\end{array}$ & $\begin{array}{l}4 / 9(44) \\
2 / 29(7) \\
1 / 12(8) \\
0 / 5\end{array}$ & $\begin{array}{l}4 / 6(67) \\
7 / 17(41) \\
1 / 6(17) \\
0 / 2\end{array}$ & $\begin{array}{r}11 / 27(41) \\
12 / 93(13) \\
2 / 37(5) \\
1 / 20(5)\end{array}$ \\
\hline Total & $7 / 91 \quad(8)$ & $7 / 55(13)$ & $12 / 31(39)$ & $26 / 177(15)$ \\
\hline $\begin{array}{c}\text { Shedding } \\
\leqslant 19 \\
20-25 \\
26-30 \\
>30\end{array}$ & $\begin{array}{l}1 / 12(8) \\
5 / 47 \text { (11) } \\
1 / 19 \text { (5) } \\
0 / 13\end{array}$ & $\begin{array}{l}1 / 9(11) \\
2 / 29(7) \\
0 / 12 \\
0 / 5\end{array}$ & $\begin{array}{l}3 / 6(50) \\
5 / 17(29) \\
0 / 6 \\
1 / 2(50)\end{array}$ & $\begin{array}{r}5 / 27(19) \\
12 / 93(13) \\
1 / 37(3) \\
1 / 20\end{array}$ \\
\hline Total & $7 / 91 \quad(8)$ & $3 / 55$ (6) & 9/31 (29) & $19 / 177(11)$ \\
\hline
\end{tabular}

and seven adenovirus isolates. Table II shows the number of women in different age groups who shed HSV and CMV.

\section{HERPES SIMPLEX VIRUS}

Of the 177 women, $26(15 \%)$ were found to shed HSV. The highest incidence $(41 \%(11 / 27))$ of virus excretion was found in the youngest age group (aged 19 or younger). Of the 26 women, 22 shed HSV II, one HSV $I$, and the isolates from three women were not available.for typing.

CYTOMEGALOVIRUS

Of the 177 women, $19(11 \%)$ were found to excrete CMV, with the highest incidence $(19 \%(11 / 27))$ in the youngest age group. We were able to obtain multiple isolates from five of the 19 women shedding CMV (see table III). In four women the positive isolates were obtained on consecutive attempts at intervals of four weeks (case 33771), 26 weeks (case 36414), 15 months (case 30064), and one to 21 weeks (case 38472). Whether these isolates resulted from persistent or latent infection is not known, as no data were available about the period between positive isolates. In the fifth woman (case 37527), however, two positive isolates were obtained at an interval of 23 weeks, during which four negative isolates were obtained. All positive isolates were analysed by restriction enzyme cleavage and appeared to be identical for each woman (figure). All five women shed different strains from each other.

TABLE III. Repeat isolates of cytomegalovirus (CMV) from five women

\begin{tabular}{|c|c|c|c|c|}
\hline Case No & Age & Date & $\begin{array}{l}\text { Isolation } \\
\text { of } C M V\end{array}$ & $\begin{array}{l}\text { Restriction enzyme } \\
\text { analysis of } \\
\text { positive isolates }\end{array}$ \\
\hline 33771 & $\begin{array}{l}19 \\
19 \\
19 \\
19\end{array}$ & $\begin{array}{l}21 / 05 / 80 \\
18 / 06 / 80 \\
25 / 06 / 80 \\
02 / 07 / 80\end{array}$ & $\begin{array}{l}\text { Positive } \\
\text { Positive } \\
\text { Negative } \\
\text { Negative }\end{array}$ & $\begin{array}{l}\text { Identical } \\
\text { (lane } D \text { in fig) }\end{array}$ \\
\hline 36414 & $\begin{array}{l}22 \\
22 \\
22 \\
22 \\
22 \\
23\end{array}$ & $\begin{array}{l}29 / 04 / 81 \\
27 / 05 / 81 \\
17 / 06 / 81 \\
29 / 07 / 81 \\
18 / 08 / 81 \\
16 / 02 / 82\end{array}$ & $\begin{array}{l}\text { Negative } \\
\text { Negative } \\
\text { Negative } \\
\text { Negative } \\
\text { Positive } \\
\text { Positive }\end{array}$ & $\begin{array}{l}\text { Identical } \\
\text { (lane } C \text { in fig) }\end{array}$ \\
\hline 30064 & $\begin{array}{l}23 \\
23\end{array}$ & $\begin{array}{l}28 / 11 / 78 \\
12 / 03 / 80\end{array}$ & $\begin{array}{l}\text { Positive } \\
\text { Positive }\end{array}$ & $\begin{array}{l}\text { Identical } \\
\text { (data not shown) }\end{array}$ \\
\hline 38472 & $\begin{array}{l}24 \\
24 \\
24 \\
25 \\
25\end{array}$ & $\begin{array}{l}13 / 05 / 81 \\
10 / 06 / 81 \\
17 / 06 / 81 \\
14 / 11 / 81 \\
08 / 04 / 82\end{array}$ & $\begin{array}{l}\text { Positive } \\
\text { Positive } \\
\text { Positive } \\
\text { Positive } \\
\text { Negative }\end{array}$ & $\begin{array}{l}\text { Identical } \\
\text { (lane A in fig) }\end{array}$ \\
\hline 37527 & $\begin{array}{l}25 \\
25 \\
25 \\
25 \\
25 \\
25\end{array}$ & $\begin{array}{l}20 / 05 / 81 \\
17 / 06 / 81 \\
08 / 07 / 81 \\
22 / 07 / 81 \\
29 / 07 / 81 \\
30 / 10 / 81\end{array}$ & $\begin{array}{l}\text { Positive } \\
\text { Negative } \\
\text { Negative } \\
\text { Negative } \\
\text { Negative } \\
\text { Positive }\end{array}$ & $\begin{array}{l}\text { Identical } \\
\text { (lane B in fig) }\end{array}$ \\
\hline
\end{tabular}




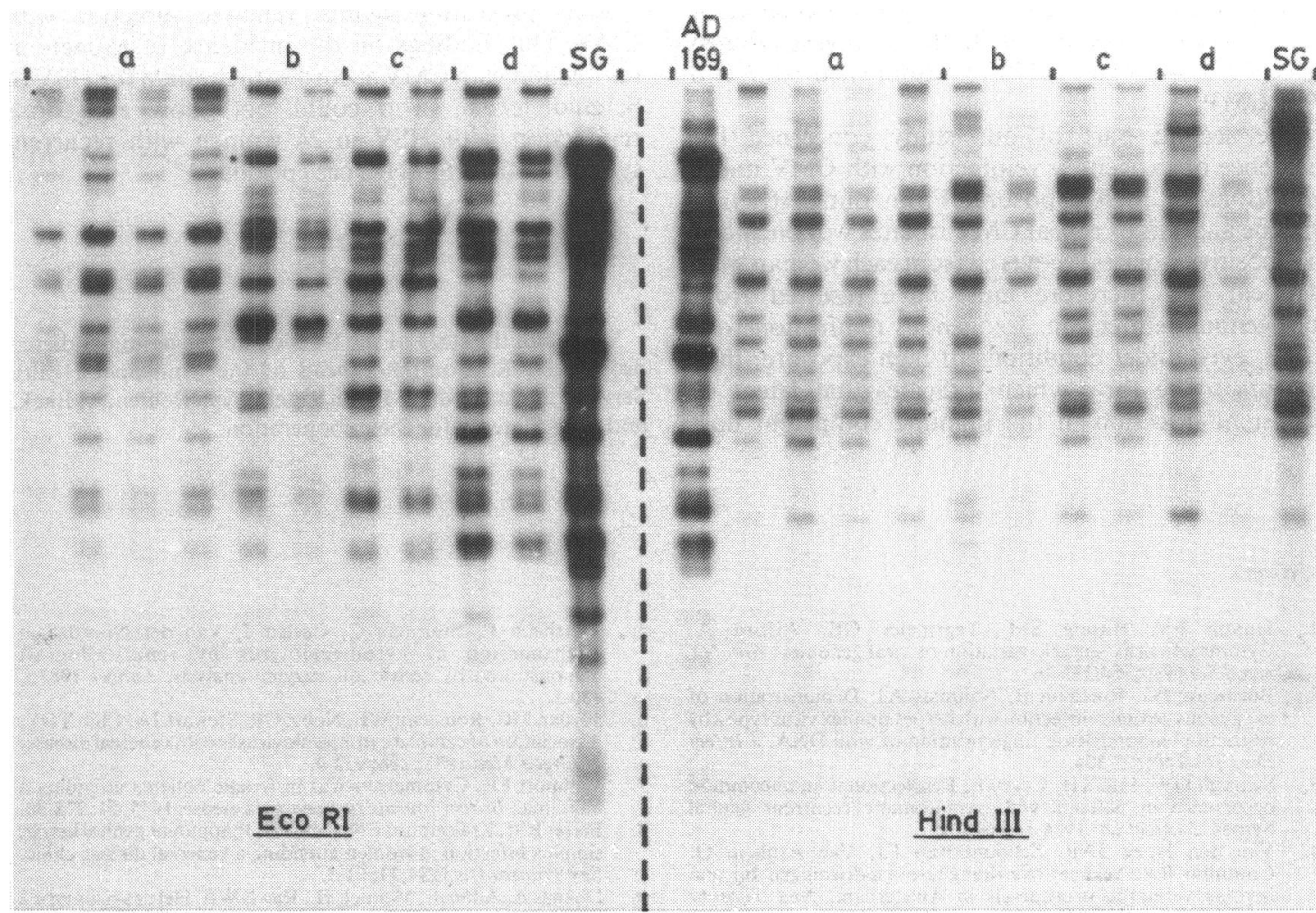

FIGURE Restriction enzyme analysis patterns of the repeat cervical isolates containing cytomegalovirus from: (a) patient 38472 (four isolates), (b) patient 37527 (two isolates), (c) patient 36414 (two isolates, and (d) patient 33771 (two isolates) and of reference strains ADI69 and SG using restriction enzymes Eco RI and Hind III.

\section{ADENOVIRUSES}

Seven adenoviruses were isolated, six of which were from women aged 20-25. Five isolates were identified as adenovirus type 37 and two as adenovirus type 2 . All adenoviruses were excreted in August to October and no repeat isolates were obtained.

\section{Discussion}

Table IV compares the results of our prospective study of the shedding of $\mathrm{HSV}$ and CMV with the results of other studies. ${ }^{4-9}$ The percentage of women excreting HSV in the study reported here $(15 \%)$ was high compared with $4 \cdot 9-7 \%$ found by other workers, probably because of the promiscuity of our study population and the number of samples obtained. As can be seen from table II, the percentage of HSV shedders can be as high as $39 \%$ when four or more samples a woman are investigated. We also found a high percentage of women $(11 \%)$ excreting CMV, which increased to $29 \%$ when four or more samples a TABLE IV Incidence of infection with herpes simplex virus (HSV) and cytomegalovirus (CMV) in high risk groups

\begin{tabular}{|c|c|c|c|c|c|}
\hline & \multicolumn{4}{|c|}{ Data from studies by: } & \multirow[b]{2}{*}{$\begin{array}{l}\text { Data from } \\
\text { this study } \\
\text { (Prostitutes) } \\
(n=177)\end{array}$} \\
\hline & $\begin{array}{l}\text { Jordan et al } \\
\text { STD clinic } \\
\text { attenders }) \\
(n=120)\end{array}$ & $\begin{array}{l}\text { Wilmott }^{7} \\
\text { (SDT clinic } \\
\text { attenders) } \\
(n=531)\end{array}$ & $\begin{array}{l}\text { Ferrer et al }{ }^{8} \\
\text { (STD clinic } \\
\text { attenders) } \\
(n=123)\end{array}$ & $\begin{array}{l}\text { Duenas et al } \\
\text { (Prostitutes) } \\
(n=343)\end{array}$ & \\
\hline $\begin{array}{l}\text { Mean age (years) } \\
\text { Mean sample number }\end{array}$ & $21 \cdot 3$ & $\begin{array}{r}21 \\
1\end{array}$ & $\begin{array}{c}26 \cdot 7 \\
1\end{array}$ & $\begin{array}{c}25 \cdot 8 \\
1\end{array}$ & $\begin{array}{r}20 \cdot 3 \\
2 \cdot 8\end{array}$ \\
\hline $\begin{array}{l}\text { Neisseira gonorrhoeae positive }(\%) \\
\text { HSV positive }(\%) \\
\text { CMV positive }(\%)\end{array}$ & $\begin{array}{r}34 \cdot 2 \\
5 \cdot 8 \\
13 \cdot 3\end{array}$ & $\begin{array}{l}43 \\
5 \cdot 3 \\
6 \cdot 6\end{array}$ & $\begin{array}{l}\text { ND } \\
4 \cdot 9 \\
\text { ND }\end{array}$ & $\begin{array}{l}\text { ND } \\
7 \cdot 0 \\
\text { ND }\end{array}$ & $\begin{array}{l}49^{*} \\
15 \\
11\end{array}$ \\
\hline
\end{tabular}

ND = No data.

* Study of same group of prostitutes by Van den Hoek et al. ${ }^{4}$ 
woman were investigated. The highest incidence of virus shedding was found in the youngest women (aged 19 or younger), $41 \%$ of whom shed HSV and $19 \%$ CMV.

The second part of our study concerned the incidence of exogenous reinfection with CMV under conditions of high exposure. From our restriction enzyme analysis of repeat CMV isolates we concluded that positive isolates recovered from each woman were identical and therefore must have resulted from endogenous reinfection. Exogenous reinfection with CMV, even under conditions of high exposure, thus appears to be rare, which indicates that latent or persistent infection in the immune competent host

References

1. Huang ES, Huong SM, Tegtmeier GE, Alford A. Cytomegalovirus: genetic variation of viral genomes. Ann NY Acad Sci 1980;354:332-46.

2. Buchman TG, Roizman B, Nahmias AJ. Demonstration of exogenous genital reinfection with herpes simplex virus type 2 by restriction endonuclease fingerprinting of viral DNA. I Infect Dis 1979;140:295-304.

3. Schmidt OW, Fife KH, Corey L. Reinfection is an uncommon occurrence in patients with symptomatic recurrent genital herpes. J Infect Dis 1984;149:645-6.

4. Van den Hoek JAR, Schoonhoven FJ, Van Arnhem Q, Coutinho RA. Sexueel overdraagbare aandoeningen bij aan heroine verlaafde protitué(e)s in Amsterdam. Ned Tijdschr Geneeskd 1984:128:272-4. confers protection against renewed infection with CMV. Our findings on the incidence of exogenous reinfection with CMV accord with the data for HSV of Schmidt et al, who could not show exogenous reinfection with HSV in 24 women with recurrent symptomatic genital herpes episodes. ${ }^{3}$

We thank the staff of the STD clinic for heroin addicted prostitutes, R. Coutinho (head of the Municipal Health Services in Amsterdam) $R$ van Ketel, $P$ van Keulen, M Baak, and $\mathbf{K}$ W Slaterus for their cooperation.

5. Wertheim P, Buurman C, Geelen J, Van der Noordaa J. Transmission of cytomegalovirus by renal allograft demonstrated by restriction enzyme analysis. Lancet 1983;i, 980-1.

6. Jordan MC, Rousseau WE, Noble GR, Stewart JA, Chin TDY. Association of cervical cytomegaloviruses with venereal disease. N Engl J Med 1973; 288: 932-4.

7. Willmott FE. Cytomegalovirus in female patients attending a VD clinic. British Journal of Venereal Disease, 1975; 51:278-80.

8. Ferrer RM, Kraiselburd EN, Kouri H. Inapparent genital herpes simplex infection in women attending a venereal disease clinic. Sex Transm Dis 1984;11: 91-3.

9. Duenas A, Adam E, Melnick JL, Rawls WE. Herpes virus type 2 in a prostitute population. Am J Epidemiol 1972; 95: 483-9. 